\title{
Pengaruh Servant Leadership dan Empowerment terhadap Organizational Citizenship Behaviour pada PT. Samaja Bali Villa
}

\author{
A.A Ngurah Yoga Indra Pratama ${ }^{1)}$ \\ Universitas Mahasaraswati Denpasar \\ Dr. Drs. I Wayan Sujana ${ }^{2)}$ \\ Universitas Mahasaraswati Denpasar \\ Ni Nyoman Ari Novarini ${ }^{3)}$ \\ Universitas Mahasaraswati Denpasar
}

agungyoga51@gmail.com, novarini0511@gmail.com

\begin{abstract}
Organizational Citizenship Behavior is a form of behavior which is an individual choice and initiative, not related to the formal reward system of the organization but in aggregate to increase organizational effectiveness. This behavior shows the added value of employees which is a form of prosocial behavior, namely social behavior that is positive, constructive and means helping.

This research was conducted at PT. Samaja Bali Villa, with the research object Servant Leadership and Empowment on Organizational Citizenship Behavior. The population in this study were employees of PT. Samaja Bali Villa. The sample of this study was determined by the Simple Random Sampling method, so that the number of samples was 47 people. The data analysis technique used is multiple linear regression analysis. In addition, in this study, a classic assumption test was also carried out which included tests of normality, heteroscedasticity and multicollinearity.

The test results show that Servant Leadership has a positive and significant effect on Organizational Citizenship Behavior at PT. Samaja Bali Villa. Empowerment has a positive and significant effect on Organizational Citizenship Behavior at PT. Samaja Bali. Based on the average score on the servant leadership variable where overall respondents have the least perception of the leadership statement items encouraging the achievement of progress and development for the company, it is better if the leadership of PT. Samaja Bali Villa is able to motivate and create a pleasant working atmosphere. So, it is hoped that it can foster employee responsibility at work in order to achieve maximum company goals. Based on the average score on the empowerment variable where overall respondents have the smallest perception of items that respect the abilities possessed by employees, the leadership of PT Samaja Bali Villa needs to give employees the right or authority to plan, control and make decisions on jobs that have become their responsibility, so that employees are able to become independent and show their best performance.
\end{abstract}

Keywords: Servant Leadership, Empowerment, Organizational Citizenship Behavior 
Anak Agung Ngurah Yoga Indra Pratama, I Wayan Sujana, Ni Nyoman Ari Novarini

\section{Pendahuluan}

\section{Latar Belakang}

Bali adalah salah satu tujuan wisata terbaik di Indonesia bahkan dunia (Noviarini \& Anggraini, 2017). Majalah Travel and Leisure menempatkan Bali sebagai pulau terbaik ke dua di dunia dan terbaik di Asia Pasifik (www.koransindo.com). Keindahan alam yang sangat beraneka ragam, mulai dari laut serta karangnya sampai kepada keindahan panorama gunung dan keunikan budayanya. Kunjungan wisatawan domestik maupun mancanegara ke Bali terus mengalami peningkatan dari tahun ke tahun (www.denpostnews.com). Kondisi seperti ini maka perusahaan harus dapat meningkatkan keterampilan sumber daya manusianya dalam pemberian informasi, bersikap, dan dalam menjalin hubungan kepada para pelanggannya. Perusahaan yang mempunyai keterampilan yang tinggi dalam pemberian pelayanan kepada pelanggannya akan mampu menguasai atau dominan di pasar (Sandra, 2018).

Sumber daya manusia merupakan salah satu faktor yang paling penting dalam suatu perusahaan. Manora (2020) menyatakan perilaku individu yang dibutuhkan adalah kemampuan interpersonal yang tergolong dalam lingkup Organizational Citizenship Behaviour (OCB). Organisasi perlu didukung karyawan yang produktif dan berkomitmen tinggi untuk mencapai tujuan secara efektif (Adelia et al.,2015). Sikap tanggung jawab dan peduli pada organisasi dibutuhkan untuk membentuk loyalitas karyawan. Karyawan juga diharapkan berperan aktif dalam menyampaikan ide dalam mencapai visi dan misi organisasi. Selain itu, kepedulian pada rekan kerja dan sikap toleran dibutuhkan untuk menciptakan suasana kerja yang kondusif (Lalujan et al.,2016). Sumber daya manusia merupakan asset paling penting dalam suatu organisasi, karena merupakan sumber yang mengendalikan organisasi serta mempertahankan dan mengembangkan organisasi dalam menghadapi berbagai tuntutan zaman (Fery,2015). Sumber daya manusia perlu dikembangkan secara terus menerus agar diperoleh sumber daya manusia yang bermutu dalam artian sebenarnya yaitu pekerjaan yang dilaksanakan akan menghasilkan sesuatu yang dikehendaki (Diana, 2015). Oleh karena itu ada deskripsi formal tentang perilaku yang harus dikerjakan (intra-role), dan yang tidak terdeskripsi secara formal yang dilakukan oleh pegawai (extra-role).

Kepemimpinan sebagai bagian integral dari efektivitas organisasi, maka kualitas dari pemimpin seringkali dianggap sebagai faktor terpenting yang menentukan keberhasilan atau kegagalan organisasi. Pemimpin yang efektif menjadikan seorang pimpinan perusahaan harus dapat mempengaruhi seluruh anggota organisasi yang dipimpinnya melalui cara-cara yang positif untuk mencapai tujuan organisasi (Sandra, 2015). Untuk menjadi pemimpin yang efektif, seseorang harus dapat mempengaruhi seluruh anggota yang dipimpinnya melalui caracara yang positif dalam berkomunikasi khususnya servant leadership model yang diterapkan (Fery,2016). Ningsih (2016) mengatakan bahwa, servant leadership merupakan gaya kepemimpinan yang sangat peduli atas pertumbuhan dan dinamika kehidupan pengikut dirinya serta komunitasnya dimulai dari perasaan natural yang ingin melayani. Kepemimpinan yang melayani diharapkan dapat menumbuhkan tanggung jawab karyawan pada pekerjaan (Sandra,2018). Perilaku-perilaku tersebut diharapkan dapat memperkecil perasaan tertekan terhadap tuntutan. Karyawan diharapkan dapat bekerja dengan produktif dan loyal pada perusahaan. Pimpinan divisi lain pada PT. Samaja Bali Villa belum seluruhnya memposisikan diri sebagai pemimpin yang melayani karyawan. Ditunjukkan dengan hubungan pemimpin dan karyawan yang kaku, dan kurang memperhatikan hak karyawan. Pimpinan juga tidak memberikan apresiasi pada prestasi dan tidak objektif dalam member penilaian terhadap pekerjaan karyawan (Sandra,2018). Hal-hal tersebut menimbulkan krisis kepercayaan terhadap 
pemimpin, dan menjadi penyebab rendahnya perilaku organizational citizenship behaviour karyawan PT.Samaja Bali Villa.

Pelayanan yang baik dan memuaskan kepada wisatawan diperlukan adanya sikap organizational citizenship behavior pada diri karyawan. Empowerment atau pemberdayaan dapat diartikan sebagai perlibatan karyawan yang benar-benar berarti (signifikan) dalam peningkatan kinerja karyawan. Empowerment suatu cara yang amat praktis dan prodiktif untuk mendapatkan yang terbaik dari diri kita dan staf kita (Stewart, 2016:22). Pemberdayaan adalah pemberian wewenang kepada karyawan untuk merencanakan (Planning), mengendalikan (Controlling) dan membuat keputusan atas pekerjaan yang menjadi tanggung jawabnya tanpa harus mendapatkan otorisasi secara eksplisit dari atasannya (Andrea, et,al.2017). (Catherine et al.2015) menegaskan pemberdayaan merupakan alat yang dilakukan perusahaan sebagai rangsangan dalam meningkatkan motivasi serta karyawan bekerja dengan melaksanakan penerapan organizational citizenship behaviour (OCB).

Berdasarkan fenomena hasil penelitian dan masalah yang terdapat pada PT. Samaja Bali Villa, maka penulis meneliti "Pengaruh Servant Leadership dan Empowerment Terhadap Organizational Citizenship Behaviour Pada PT. Samaja Bali Villa”.

Berdasarkan latar belakang yang dipaparkan oleh penulis maka dapat dirumuskan masalahnya, yaitu :

1) Apakah ada pengaruh servant leadership terhadap organizational citizenship behaviour pada PT. Samaja Bali Villa?

2) Apakah ada pengaruh empowerment terhadap organizational citizenship behaviour pada PT. Samaja Bali Villa?

\section{Tinjauan Pustaka}

\section{Sumber Daya Manusia}

Sumber daya manusia merupakan satu-satunya sumber daya yang memiliki akal perasaan, keinginan, keterampilan, pengetahuan, dorongan, daya, dan karya (rasio, rasa, da karsa) (Sutrisno, 2016:3). (Ardana dkk,2012:3) menyatakan bahwa sumber daya manusia adalah harta atau aset yang paling berharga dan paling penting dimiliki oleh suatu organisasi, karena keberhasilan organisasi sangat ditentukan oleh unsur manusia. Sumber daya manusia yang sangat diperhitungkan dalam organisasi, jika keberadaan sumber daya manusia disepelekan maka organisasi tidak akan dapat mewujudkan tujuan mereka, dari pengertian di atas dapat disimpulkan bahwa sumber daya manusia memiliki akal, pikiran, skill, kreatifitas dan bakat yang membantu organisasi mencapai tujuan yang telah ditetapkan.

\section{Servant Leadership}

Servant Leadership dapat didefinisikan Kepemimpinan yang melayani adalah suatu kepemimpinan yang berawal dari perasaan tulus yang timbul dari hati yang berkehendak untuk melayani, yaitu untuk menjadi pihak pertama yang melayani (Heider et al., 2015). Trompenaars dan Voerman (2015:3) Menurut Trompenaars dan Voerman, servant leadership adalah gaya manajemen dalam hal memimpin dan melayani berada dalam satu harmoni, dan terdapat interaksi dengan lingkungan. Seorang servant leadership adalah seseorang yang memiliki keinginan kuat untuk melayani dan memimpin, dan yang terpenting adalah mampu menggabungkan keduanya sebagai hal saling memperkuat secara positif. Vondey (2016) Servant Leadership adalah seorang pemimpin yang sangat peduli atas 
pertumbuhan dan dinamika kehidupan pengikut, dirinya serta komunitasnya, karena itu ia mendahulukan hal tersebut daripada pencapaian ambisi pribadi (personal ambitious) dan kesukaannya semata.

\section{Empowerment}

Riedmann dalam Prijono dan Pranaka (2015) Menurtutnya, empowerment adalah kekuatan aspek sosial ekonomi masyarakat menjadi akses terhadap dasar-dasar produksi tertentu suatu rumah tangga yaitu informasi, pengetahuan dan keterampilan, partisipasi dalam organisasi dan sumber-sumber keuangan, ada korelasi yang positif, bila ekonomi rumah tangga tersebut meningkatkan aksesnya pada dasar-dasar produksi maka akan meningkat pula tujuan yang dicapai peningkatan akses rumah tangga terhadap dasar-dasar kekayaan produktif mereka. Menurut Priyono dan Pranarka (2016) Pengertian empowerment sejatinya mengandung dua arti, yang pertama empowerment memiliki peran sebagai memberi atas kekuasaan atau mampu mengalihkan ke pihak lainnya. Sedangkan kedua dapat dipahami jika arti empowerment adalah suatu upaya untuk memberikan keberdayaan dan kemampuan kepada pihak lain.

Slamet (2015) definisi pemberdayaan adalah upaya yang dilakukan untuk membuat masyarakat agar mampu membangun dirinya sendiri sehingga masyarakat dapat memperbaiki kehidupannya. Arti ini secara tidak langsung pemberdayaan diartikan sebagai kesempatan dalam melihat dan memanfaatkan peluang sehingga mampu mengambil suatu keputusan yang tepat yang sesuai dengan inisiatifnya.

\section{Organizational Citizenship Behaviour}

Organ (dalam Ritonga, 2015), Organizational Citizenship Behavior merupakan bentuk perilaku yang merupakan pilihan dan inisiatif individual, tidak berkaitan dengan sistem reward formal organisasi tetapi secara agregat meningkatkan efektivitas organisasi. perilaku ini menunjukkan nilai tambah karyawan yang adalah salah satu bentuk tingkah laku prososial, yakni tingkah laku sosial yang positif, konstruktif dan berarti membantu. Menurut Organ (dalam Organ, Podsakoff, dan MacKenzie, (2012), Organizational Citizenship Behavior OCB adalah perilaku individu yang bebas, bebas dalam arti bahwa perilaku tersebut bukan merupakan persyaratan yang harus dilaksanakan dalam peran tertentu atau deskripsi kerja tertentu, atau perilaku yang merupakan pilihan pribadi (MacKenzie dan Podsakoff, 2012).

\section{Kerangka Berpikir dan Rumusan Hipotesis}

\section{Kerangka Berpikir}

Kerangka konseptual yang merupakan hubungan variabel-variabel yang diteliti meliputi Servant Leadership $\left(\mathrm{X}_{1}\right)$, Empowerment $\left(\mathrm{X}_{2}\right)$ dan Organizational Citizenship Behaviour $(\mathrm{Y})$, dapat digambarkan kerangka berpikir penelitian berikut ini: 


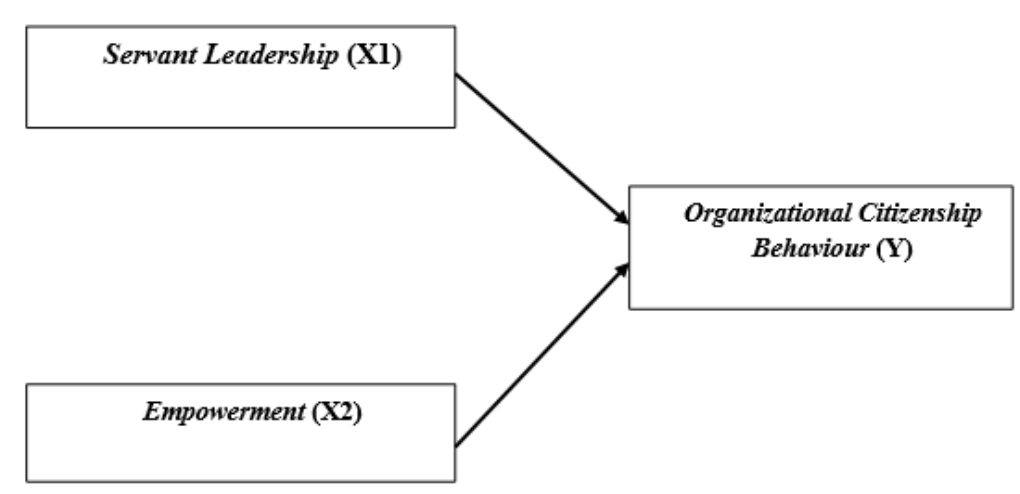

Gambar 1. Kerangka Berpikir

Sumber: Hasil pemikiran peneliti (2020)

\section{Hipotesis}

$\mathrm{H}_{1}$ : Servant leadership berpengaruh positif dan signifikan terhadap organizational citizenship behaviour

$\mathrm{H}_{2}$ : Empowerment berpengaruh positif dan signifikan terhadap organizational citizenship behaviour

\section{Metode Penelitian}

\section{Lokasi Penelitian}

Penelitian ini dilakukan PT. Samaja Bali Villa. Dalam penelitian ini yang menjadi populasi adalah karyawan PT. Samaja Bali Villa.

\section{Objek Penelitian}

Obyek pada penelitian ini adalah bidang manajemen sumber daya manusia yaitu pengaruh Servant Leadership dan Empowement Terhadap Oganizational Citizenship Behaviour Pada PT. Samaja Bali Villa.

\section{Definisi Operasional Variabel}

\section{Servant Leadership $\left(\mathrm{X}_{1}\right)$}

Pemimpin yang berorientasi pelayanan memulai tindakannya dengan integritas, mengembangkan hubungan kepercayaan, dan membantu orang lain untuk belajar, tumbuh, dan mengembangkan kemampuan orang-orang tersebut untuk memimpin diri mereka sendiri. Barbuto (dalam Aji 2015) menyatakan terdapat 7 indikator sebagai berikut :
a. Tindakan
b. Empati
c. Bijaksana
d. Mencari solusi
e. Tumbuh 
f. Berjiwa sosial

g. Melayani

\section{Empowement $\left(\mathbf{X}_{2}\right)$}

Serangkaian dukungan untuk meningkatkan kemampuan serta memperluaskan segala akses kehidupan sehingga mampu mendorong kemandirian yang berkelanjutan terhadap karyawan/masyarakat. Khan (dalam Fajriana 2017) menyatakan terdapat 6 indikator yang meliputi yaitu :
a. Keinginan
b. Kepercayaan
c. Percaya diri
d. Kredibilitas
e. Pertangungjawaban
f. Komunikasi

\section{Oganizational Citizenship Behaviour (Y)}

Perilaku yang merupakan pilihan dan inisiatif individual, tidak berkaitan dengan sistem reward formal organisasi tetapi secara agregat meningkatkan efektivitas organisasi. perilaku ini menunjukkan nilai tambah karyawan yang adalah salah satu bentuk tingkah laku prososial, yakni tingkah laku sosial yang positif, konstruktif dan berarti membantu. Organ (dalam Wulandari, 2017), Organizational Citizenship Behavior (OCB) terdiri dari 5 indikator, yaitu :
a. Perhatian
b. Kebijakan
c. Hati nurani
d. Kesopanan
e. Sportif

\section{Metode Penelitian}

Alat analisis yang digunakan adalah analisis regresi linier berganda dengan menggunakan program SPSS. Populasi Populasi dalam penelitian ini adalah seluruh karyawan PT. Samaja Bali Villa yang berjumlah 47 orang. Teknik dalam penelitian ini adalah Sampling jenuh. Jadi jumlah responden dalam penelitian ini adalah 47 orang karyawan pada PT. Samaja Bali Villa. Karena semua anggota populasi dijadikan sampel dengan menggunakan teori Sugiyono (2002 : 61-63) yang mengatakan bahwa sampling jenuh adalah tehnik penentuan sampel bila semua anggota populasi digunakan sebagai sampel. Istilah lain dari sampel jenuh adalah sensus.

\section{Hasil Analisis dan Pembahasan}

\section{Hasil Analisis Regeresi Linier Berganda}

Hasil analisis regresi linier berganda untuk mengetahui pengaruh antara servant leadership dan Empowerment terhadap Organizational Citizenship Behaviour pada PT Samaja Bali Villa secara parsial dapat dilihat pada tabel berikut : 
Tabel 1.

Hasil Uji Regresi Linier Berganda

\begin{tabular}{|l|r|c|c|c|c|}
\hline \multirow{2}{*}{ Variabel } & \multicolumn{2}{|c|}{$\begin{array}{c}\text { Unstandardized } \\
\text { Coefficients }\end{array}$} & $\begin{array}{c}\text { standardized } \\
\text { Coefficients }\end{array}$ & \multirow{2}{*}{$\mathrm{t}$} & \multirow{2}{*}{ Sig } \\
\cline { 2 - 5 } & $\mathrm{B}$ & $\begin{array}{c}\text { Std. } \\
\text { Eror }\end{array}$ & Beta & & \\
\hline (Constant) & 3,403 & 2,977 & & 1,143 & 0,259 \\
\hline Servant leadership & 0,311 & 0,103 & 0,384 & 3,020 & 0,004 \\
\hline Empowerment & 0,269 & 0,100 & 0,342 & 2,690 & 0,010 \\
\hline R & & & & 0,559 \\
$R$ Square & & & 0,312 \\
Adjusted $R$ S Square & & & & 0,281 \\
F Statistic & & & 9,984 \\
Signifikansi & & & & 0,000 \\
\hline
\end{tabular}

Berdasarkan nilai-nilai tersebut di atas, maka diperoleh persamaan regresi linier berganda sebagai berikut:

$$
\begin{aligned}
& \mathrm{Y}=a+\beta_{1} \mathrm{SL}+\beta_{2} \mathrm{EM}+e \\
& \mathrm{Y}=3,403+0,311 \mathrm{SL}+0,269 \mathrm{EM}
\end{aligned}
$$

\section{Analisis Koefisien determinasi (R2)}

Berdasarkan Tabel 5.1 di atas, diperoleh nilai koefisien korelasi berganda sebesar 0,312. Dengan demikian besarnya pengaruh servant leadership dan empowerment terhadap organizational citizenship behaviour pada PT Samaja Bali Villa adalah sebesar 31,2\% sedang sisanya $100 \%-31,2 \%=68,8 \%$ dipengaruhi faktor-faktor lain yang tidak diteliti.

\section{Uji t}

Hasil pengujian t-test pengaruh servant leadership dan empowerment terhadap organizational citizenship behaviour pada PT Samaja Bali Villa pada tabel 5.1 menunjukkan bahwa :

1) Pengaruh Servant Leadership terhadap Organizational Citizenship Behavior pada PT Samaja Bali Villa menunjukkan nilai thitung sebesar 3,020 serta nilai signifikan uji t sebesar 0,004 yang lebih kecil dari $\alpha$ (taraf nyata) $=0,05$, maka dapat disimpulkan bahwa Servant Leadership berpengaruh positif dan signifikan terhadap Organizational Citizenship Behavior pada PT Samaja Bali Villa, sehingga hipotesis pertama $\left(\mathrm{H}_{1}\right)$ diterima.

2) Pengaruh Empowerment terhadap Organizational Citizenship Behavior pada PT Samaja Bali Villa menunjukkan nilai thitung sebesar 2,690 serta nilai signifikan uji t sebesar 0,010 yang lebih kecil dari $\alpha$ (taraf nyata) $=0,05$, maka dapat disimpulkan bahwa Empowerment berpengaruh positif dan signifikan terhadap Organizational Citizenship Behavior pada PT Samaja Bali Villa, sehingga hipotesis kedua $\left(\mathrm{H}_{2}\right)$ diterima. 


\section{Simpulan, Keterbatasan dan Saran}

\section{Simpulan}

1. Servant Leadership berpengaruh positif dan signifikan terhadap Organizational Citizenship Behavior pada PT. Samaja Bali Villa.

2. Empowerment berpengaruh positif dan signifikan terhadap Organizational Citizenship Behavior pada PT. Samaja Bali.

\section{Keterbatasan}

1. Penelitian ini hanya menguji servant leadership dan empowerment terhadap organizational citizenship behaviour. Bagi peneliti selanjutnya diharapkan dapat menambahkan faktor lain yang mempengaruhi Organizational Citizenship Behavior seperti: gaya kepemimpinan, kepuasan kerja dan komitmen organisasi.

\section{Saran}

1. Berdasarkan rata-rata skor pada variabel servant leadership dimana secara keseluruhan responden mempunyai persepsi yang paling kecil terhadap item pernyataan pimpinan mendorong tercapainya kemajuan dan perkembangan bagi perusahaan, maka sebaiknya pimpinan PT. Samaja Bali Villa mampu memotivasi dan menciptakan suasana kerja yang menyenangkan. Sehingga, diharapkan dapat menumbuhkan tanggung jawab karyawan pada pekerjaan demi tercapainya tujuan perusahaan secara maksimal.

2. Berdasarkan rata-rata skor pada variabel empowerment dimana secara keseluruhan responden mempunyai persepsi yang paling kecil terhadap item menghargai kemampuan yang dimiliki oleh karyawan, maka pimpinan PT Samaja Bali Villa perlu memberikan karyawan hak atau wewenang untuk merencanakan (Planning), mengendalikan (Controlling) serta membuat keputusan atas pekerjaan yang sudah menjadi tanggung jawab mereka, sehingga karyawan mampu menjadi mandiri dan menunjukkan kinerja terbaiknya.

\section{Daftar Pustaka}

Adelia, Maris., Wiji Utami., dan Dewi Prihatini. 2015. Pengaruh Servant Leadership dan Kepribadian terhadap Organizational Citizenship Behavior dalam Meningkatkan Kinerja Guru di Sekolah Dasar Al-Baitul Amien (Full Day School) Jember. Artikel Ilmiah Mahasiswa, pp: 1-7.

Aji, Muhammad. 2015. Pengaruh Servant Leadership Terhadap Kinerja Dengan Burnout Sebagai Variabel Intervening Pada Karyawan PT Intiroda Makmur Persada Tbk, Tangerang. Skripsi. Jurusan Manajemen Fakultas Ekonomi Universitas Negeri Semarang.

Andrea, R. Dake., Jeffrey Wong., and Stephen B. Salter. 2017. Empowerment, Motivation, and Performance: Examining the impact of feedback and Incentives on Nonmanagement Employes. Journal of Behavior Research in Acounting, Vol. 19, No. 1, pp. 71-89.

Ardana, I Komang, dkk. 2012. Manajemen Sumber Daya Manusia. Yogyakarta: Grahailmu. 
Catherine, Cheung., Tom Baum., and Alan Wong. 2015. Relocating empowerment as a management concept for Asia. Journal of Business Research, 6(5): 36 \pm 41 .

Diana, Rika. 2015. Sumber Daya Manusia Dan Produktivitas Kerja. Jurnal, No. 15, pp. 89103.

Fajriana. 2017. Pengaruh Empowerment, Self Efficacy, Dan Budaya Organisasi Terhadap Kinerja Karyawan (Studi pada Karyawan PT. Holcim Indonesia Tbk di Cilacap). Skripsi. Program Studi Manajemen Fakultas Ekonomi Universitas Muhammadiyah Purworejo.

Fery, Handi Putra. 2015. Analisis Pengaruh Komunikasi Interpersonal, Lingkungan kerja fisik dan disiplin kerja terhadap kinerja pegawai perpustakaan IAIN Iman Bonjol Padang. Tesis. Manajemen Universitas Bung Hatta.

Heider, Abid Raza, Amir Gulzar., and Waqar Hussain. 2015. The impact of servant leadership on organizational citizenship behaviors with the mediating role of trust and moderating role of group cohesiveness A Study of public Sector of Pakistan. International Journal of Academic Research in Business and Social Sciences. 5(3):234-242.

Lalujan, Paramita., Victor P.K. Lengkong., dan Greis M. Sendow. 2016. Pengaruh Komunikasi Organisasi dan Stress Kerja Terhadap Kepuasan Kerja Serta Dampaknya Terhadap Kinerja Karyawan di Perusahaan Umum Bulog Divisi Regional Sulawesi Utara. Jurnal Emba, 4(1): 131-142.

Manora, Retmita Tata Elsa. 2020. Pengaruh Servant Leadership, Empowerment Dan Komitmen Organisasi Terhadap Organizational Citizenship Behavior (OCB) Pada Karyawan Royal Hotel N'lounge Jember. Skripsi. Jurusan Manajemen Fakultas Ekonomi Dan Bisnis Universitas Jember.

Novarini,Ni Nyoman., \& Anggraini, Ni Putu Nita. 2017. Analisis Pengaruh Kualitas Layanan, Citra Dan Promosi Terhadap Tingkat Kepuasan Pengunjung Pada Hidden Canyon Beji Guwang. Jurnal, Vol. 15, No.2, pp. 110-117

MacKenzi, S.B and Podsakoff. 2012. Common Method Bias in marketing causes, mechanism and proceduralremedies. Journal of retailing $88: 542-555$

Prijono, Onny. Pranarka. 2015. Pemberdayaan Konsep, Kebijakan, dan Implementasi. Jakarta: Centre For Strategic And International Studies.

Ritonga, Eni Erlina. 2018. Peran Organizational Citizenship Behavior Sebagai Pemediasi Pengaruh Kepuasan Kerja Terhadap Kinerja Perawat. Jurnal, Vol. 14, No. 1, pp 1-16.

Sandra, Putu Agung Pratama., Suwandana, I Gst Made. 2018. Pengaruh Servant Leadership Dan Empowerment Terhadap Organizational Citizenship Behaviour Pada Karyawan Asa Villa Seminyak. Jurnal, Vol. 7, No. 1, pp. 29-55.

Slamet, Margono. (2003). Pemberdayaan Masyarakat di Era Global. Bandung. Alfabeta

Stewart, Aileen Mitchell, 2016. Empowering People, Cetakan kedelapan, Kansius, Yogyakarta Sugiyono. 2002. Metode penelitian administrasi. Bandung: Alfabeta

Sutrisno, Edy. 2016. Manajemen Sumber Daya Manusia. Kencana Prenada Media Group: Jakarta.

Vondey, M. 2016. The Relationships among Servant Leadership, Organizational Citizenship Behavior, Person-Organization Fit, and Organizational Identification. International Journal.

Wulandari, Ambar Dwi. 2017. Analisis Pengaruh Dukungan Organisasi Dan Pengembangan Karir Terhadap Organizational Citizenship Behavior Melalui Employee Engagement Sebagai Variabel Intervening. Skripsi. Fakultas Ekonomika Dan Bisnis Universitas Diponegoro. Semarang 